\title{
The Investment Opportunity, Information Technology and Financial Performance of SMEs
}

\author{
Theresia Dwi Hastuti \\ Faculty of Economics and Business \\ Department of Accounting, \\ Soegijapranata Catholic University \\ Semarang, Indonesia \\ theresiadwihastuti@gmail.com
}

\author{
Ridwan Sanjaya \\ Faculty of Computer Science, \\ Department of Information System \\ Soegijapranata Catholic University \\ Semarang, Indonesia \\ ridwan@unika.ac.id
}

\author{
Freddy Koeswoyo \\ Faculty of Economics and Business \\ Department of Accounting \\ Soegijapranata Catholic University \\ Semarang, Indonesia \\ freddy@unika.ac.id
}

\begin{abstract}
Financial statements as a tool for show the company financial performance and can be used as a basis for making economic decisions. Understanding of accounting standards specifically for SMEs can help SMEs in making business decisions. Information technology support and investment opportunity in SMEs are important factors that can help improve the financial performance of SMEs. Investment opportunity can be seen from the development of market tastes and reflection on the development of SMEs businesses. Investment opportunity is also obtained by innovating in production and marketing. The development of the SMEs business is in line with increasing business age. This shows the ability to survive batik business in facing the times and business competition. This study examines the factors that influence the financial performance of SMEs. using a sample of batik craftsmen. Data analysis was performed using multiple regression program which are currently widely used by researchers to test the research model that they formulate. The result of this research were (1) for small and medium-sized enterprises (SMEs), the company's age and investments opportunity greatly affect the company's financial performance. (2) IT support and good financial management in small and medium enterprises (SMEs) do not affect the company's financial performance.
\end{abstract}

Keywords- Financial Management, Investment opportunity, Information Technology, Financial Performance, Small Medium Enterprise

\section{INTRODUCTION}

Small medium Enterprise (SMEs) function as growth engines for national development for most developing countries. Data from the Indonesian Central Statistics Agency shows that, after the economic crisis in Indonesia in 1997-1998, the number of small and medium enterprises (SMEs) did not decrease, instead it continued to increase, even able to absorb 85 million to 107 million workers until 2012. In that year, the number of companies in Indonesia is 56.539.560 units. Of these, the SMEs amounted to 56.534 .592 units or $99.99 \%$. The rest, around $0.01 \%$ or 4.968 units are big companies. The data shows that, SMEs have a market opportunity for the financial services industry, especially banks to give financing. That is cause about 60 $70 \%$ of SMEs do not yet have access to bank financing.
The government and legislative bodies have proven their concern for SMEs by launching Law No. 20 of 2008 concerning SMEs. With regulations that form the basis of law, SMEs are growing fast. This is because the Law regulates the expansion of funding and facilities by banks and non-bank financial service institutions. However, there are many other problems faced by SMEs and require good managerial skills to overcome various forms of problems. The problem of financial reporting is one of the main factors that inhibits the development of SMEs.

Financial reporting is the process of communicating financial information useful for making investment, credit,

The financial condition of SMEs is very dependent on the ability of management to manage their finance, therefore the managerial ability of SMEs is very important to maintain business continuity. The management of SMEs is demanded to be able to make.

\section{LITERATURE REVIEW}

\section{A. Small and Medium Enterprises (SMEs)}

Law No. 20 of 2008 issued by the Indonesian government states that a small company is a business established by individuals or companies that are notsubsidiaries or not a branch of a company that is owned and controlled directly and indirectly by the Medium Enterprise. Medium Enterprises is a business that are established by individuals or companies that are not subsidiaries or branch company that is owned, controlled, directly and indirectly by Big Enterprise. In general, SMEs is a type of business that is privatelyestablished. Including small and medium enterprises are all small and medium traders, small and medium service providers, small and medium farmers and breeders, smallscale handicrafts and small industries, etc. Classification of companies based on assets and sales value can be seen in the table below.

TABLE 1. CRITERIA FOR SMES AND BIG ENTERPRISE BASED ONASSETS AND TUNOVER

\begin{tabular}{|c|c|c|}
\hline BUSINESS SIZE & ASET (IDR) & $\begin{array}{l}\text { SALES VALUE } \\
\text { (IDR) }\end{array}$ \\
\hline Micro Business & $<=50$ million & $<=300$ million \\
\hline Small Business & $\begin{array}{c}>50 \text { million }-500 \\
\text { million }\end{array}$ & $\begin{array}{c}>300 \text { million }-2,5 \\
\text { billion }\end{array}$ \\
\hline Medium Business & $\begin{array}{c}>500 \text { million }-10 \\
\text { billion }\end{array}$ & $\begin{array}{l}>2,5 \text { billion }-50 \\
\text { billion }\end{array}$ \\
\hline Big Business & $>10$ billion & $>50$ billion \\
\hline
\end{tabular}

Source:Ministry of Cooperatives and Small and Medium Enterprises, 2012 


\section{B. Business Age}

Companies that have been established for a long time certainly have the ability to prepare financial statementsbetter compared to a company that was recently founded. The age of the company shows how long the company has existed, able to compete and take advantage of business opportunities in an economy (Istanti, 2009).

A company that has long been established, probably has a lot of experience gained. In addition, long-established companies certainly have better strategies for stayingsurvive in the future. From the description above, it can be concluded that the age of the company is a period of time for the operation of a company starting from the date of establishment and stated in years. The age of the company can be determined from the date of establishment of the company.

Small businesses tend to perform very well but up to a certain size where they become sluggish. These businesses if they are entrepreneurial tend to perform well and if not, they are more likely to fail than older businesses who are more experienced and better resourced endowed (Urban, 2004). A longitudinal study found that entrepreneurial orientation has positive long-term effects on the growth and financial performance of small firms.

Alasadi and Abdelrahim (2007) pointed in their study where business performance was measured in terms of size (number of employees) and sales growth, indicated that when size of firm is used as performance measure, accounting, technology and purchasing were proved significant influential factors. Their study concluded that older firms have poor performance when compared with younger firms. But, (Takahashi,2009) pointed that bigger businesses can enjoy economies of scale as they are able to exploit available resources better than smaller business. Achieving economies of scale means bigger businesses can produce a larger quantity of outputs with low costs because they have the capacity to access critical resources like business finance. This leads to competitive advantage and better performance.

\section{Financial Management}

Financial management may be defined as planning, organising, directing and controlling the financial activities of an organisation. Financial management also means, the activity concerned with the planning, raising, controllingand administering of funds used in the business. It is the processes and procedures used by an organisation's management to exercises financial control and accountability. These measures include recording, verification and timely reporting of transactions that affect revenues, expenditure, asserts and liabilities. (Diamond \& Khemani, 2005). Most SMEs experience losses and negativecash flows during their start up period. Financial management is very important during this time. Owner mustmake sure that they have enough cash on hand to pay employees and suppliers even though they have more money going out than coming in during the early months of the business. A good financial management system enables the company to get big picture about financial performance.

\section{Investment Opportunity}

Investment can be interpreted as investing in an activity that has a relatively long period of time in various business fields. Investments that are invested in a narrow sense in the form of certain projects, whether physical or non-physical, such as factory construction projects, roads, bridges, building construction and research projects, anddevelopment. (Kasmir $\&$ Jakfar, 2012). Two main classes ofinvestment are (1) Fixed income investment such as bonds, fixed deposits, preference shares, and (2) Variable income investment such as business ownership (equities), or property ownership. In economics, investment means creation of capital or goods capable of producing other goods or services. Expenditure on research and developmentin intellectual capital.

\section{E. Information Technology}

Information technology is a set of tools that help you work with information and perform tasks related to information processing.(Haag \& Keen, 1996). According to Williams and Sawyer, that the notion of information technology is technology that combines computing (computers) with highspeed communication lines that carrydata, voice, and video. (Williams \& Sawyer, 2003). Data processing into information can be done manually or by using electronic equipment such as computers. Advances in computer technology have had a tremendous impact on all aspects of business activities. Accounting, of course, is inseparable from these impacts. In a manual accounting system, data as input is processed into information as output by hand. In a computerized accounting system or more commonly called Electronic Data Processing, data as input is also processed into information as output. The advantage that can be clearly seen from the use of this computer is the speed, accuracy, and ease in processing data into accounting information. Computerization has enabled automation of theaccounting information systems of business organizations to help streamline processes and brought improvement in efficiency and communication.

\section{F. Financial Performance}

The most commonly considered dimensions of performance were related to efficiency, growth and profit. Efficiency comprises some financial measures like return on investment and return on equity; growth focuses on increase in sales, employees or market share; and profit includes return on sales and net profit margin (Murphy et.al., 1996). In this study, the sample used is micro and small companies that do not understand accounting standards, and do not have proper accounting records, therefore information about financial statements is not available. The most probable measure for assessing financial performance can only be based on average sales value per year. Average Sales Value per year was measured through the following categories : less than 120 million, less than 300 million, less than 1,2 billion, less than 2,5 billion, more than 2,5 billion 


\section{RESEARCH Model AND HypotheSis DEVELOPMENT}

\section{A. Research Model}

The model in this study can be described in the following scheme :

Fig.1. RESEARCH MODEL

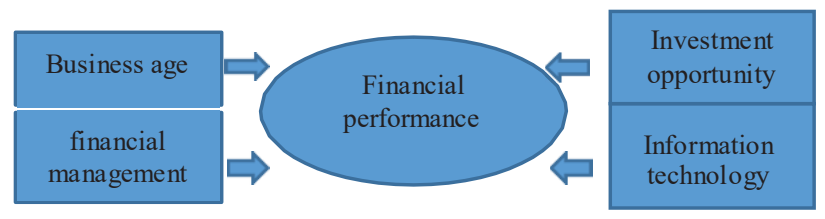

This study will examine the factors that influence financial performance. We want to test whether the factors of age of the company, financial management, investment opportunity and information technology affect the financial performance of batik small and medium enterprises in Lasem.

\section{B. Hypothesis Development}

\section{1) Business Age}

Literature on small business survival suggests that younger businesses in their formative years are more likely to be concerned with survival than growth if they do not fail within the first few years of starting up (Cowling, 2006). Therefore, growth should be observed in more matured businesses which have passed the 'survival mode'. On the other hand, older firms may also suffer from 'liabilities of age', such as the owners' lower commitment and involvement compared to young firms (Churchill \& Lewis, 1983), and a firm's performance is usually found to be diminishing as the firm ages (Chandler \& Hanks, 1993); 1994; (Durand and Coeurderoy, 2001); (Nunes, 2013); (Yasuda, 2005). From a learning perspective, however, business performance is likely to improve as both the firm and entrepreneurs become more aged and thus experienced (Vassilakis, 2008). In this study business age was measured through the following categories: less than 25 year; 26-40 years; 41-55 years; and more than 55 years. Based on the explantion above, we have following hypothesis:

$\mathrm{H1}$ : Business age has a positive effect on the financial performance of Lasem batik SMEs

\section{2). Financial Management}

In the prior study showed that there is a weak positive relationship between working capital management as a proxy of finansial management and financial performance. Good working capital management was demonstrated by thefact that majority of the SMEs studied had bank accounts; use cash budgets to make decisions; have internal control oncash; separates cash duties from other duties; have their management trained on working capital management; and the sales are reconciled with inventory. (Nthenge \& Ringera, 2017). Based on the explantion above, we have following hypothesis:

$\mathrm{H} 2$ : Financial management has a positive effect on the financial performance of Lasem Batik SMEs.

\section{3). Investment Opportunity}

It is a commonly held view that $R \& D$ makes a vital contribution to firms'sales performance, productivity and profit (Griliches, 1988); (Geroski et.al., 1993); (Jones, 1995); ( Reenen, 1997). Firms invest in R\&D in order to enhance their competitiveness and capability to earn profits. (Hesmati and Loof ,2008) found the level of R\&D is a good predictor of financial performance of firms, they are far from being able to establish the nature of causal relationships between the key investment and performance variables. R\&D is found to be a good predictor of future growth in profit and employment. Batik business is a type ofcreative business.

For creative businesses, continuous innovation is needed to be able to find new colors, new patterns, new production techniques. Therefore the batik business in Lasem needs to invest in research and development Based on the explantion above, we have following hypothesis:

H3: Investment opportunity has a positive effect on the financial performance of Lasem batik SMEs

\section{4). Information Technology}

The relationship between the use of IT and firm performance has widely researched over the recent years. The results have shown a significant and positive correlation between IT and firm performance. (Fouad, 2013) concluded to sum up the constraints of the SMEs sector are often confronted with problems that are uncommon to the larger companies and multi-national corporations. There were many problems in small medium enterprice (1) The difficulty of SMEs to attract good IT personnel. Moreover, good IT personnel are expensive and may not be affordable by most SMEs. (2). Lack of Formal Procedure and Discipline.

Information technology plays an important role in the increase of productivity and economic activities. IT does not only help in increasing productivity but also quality and make the way business operate less complicated, give time saving, and disclose the new trends of business (Olusola and Oluwaseun, 2013).

SMEs should have investment in implementing accounting information systems to be able to compete in environment change becomes more competitive (Tuanmat and Smith, 2011). Thereby, businesses in different sectors have different information processing needs and different levels of sophistication in their information system needs (Thong, 1999). We have following hypothesis:

H4: information technology has a positive effect on the financial performance of Lasem batik SMEs

\section{REASEARCH METHODS}

\section{A. Population and Samples}

The population in this study are Lasem batik craftsmen. The sample selection uses a purposive sample method with the criteria : (1) The Craftsmen already have a small or medium-sized company and (2) They are willing to be respondents of this study. The number of samples in this study were 78 Lasem batik craftsmen. 
B. Descriptive Statistic

TABLE 2. DESCRIPTIVE STATISTIC

\begin{tabular}{|c|r|r|r|r|r|}
\hline variable & \multicolumn{1}{|c|}{ N } & \multicolumn{1}{c|}{ Min } & \multicolumn{1}{c|}{ Max } & Mean & \multicolumn{1}{c|}{$\begin{array}{c}\text { Std. } \\
\text { Deviation }\end{array}$} \\
\hline FP & 78 & 1.00 & 3.00 & 1.2436 & 0.51436 \\
BA & 78 & 1.00 & 4.00 & 2.0256 & 1.09277 \\
FM & 78 & 1.00 & 3.00 & 1.3974 & 0.70875 \\
PI & 78 & 1.00 & 3.00 & 1.3590 & 0.70203 \\
TI & 78 & 1.00 & 3.00 & 1.8846 & 0.70214 \\
Valid N & 78 & & & & \\
(listwise) & & & & & \\
\hline
\end{tabular}

1. FP (financial performance), the mean of financial performance is at a value 1,2436 meaning that its financial performance is still relatively small

2. BA (Business Age, ) the mean age of the respondent's business is at a value of 2,0256 meaning that the business established by batik entrepreneurs is at an age of more than 25 years to 40 years.

3. FM (financial management), the mean of financial management is at value 1,3974 meaning that financial management capacity tends to be still lacking

4. PI (investment opportunity), the mean of investment opportunity is at value 1,3590 meaning that investment opportunity owned by batik entrepreneurs have little investment opportunity.

5. TI (information technology), the mean of technology information is at value 1,8846 meaning that Batik entrepreneurs use quite well information technology in managing their businesses, both in financial management, and in marketing

\section{RESUlt AND Discussion}

\section{A. Coefficien of Determination Analysis}

Based on the table above it can be seen that the coefficient of determination shows the Adjusted R Square value of 0.333 . This means that variations in business age, financial management, investment opportunity and information technology on the financial performance of small and medium enterprises are able to explain the changes in the financial performance of SMEs by $33.3 \%$. While the rest can be explained by other variables not examined in this study.

\section{TABLE 3. COEFFICIENT OF DETERMINATION}

\begin{tabular}{|c|c|r|r|r|r|}
\hline \multirow{2}{*}{ Model } & \multicolumn{5}{|c|}{ Model summary $^{\mathbf{b}}$} \\
\cline { 2 - 6 } & $\mathrm{R}$ & $\begin{array}{c}\mathrm{R} \\
\text { Square }\end{array}$ & $\begin{array}{c}\text { Adjusted R } \\
\text { Square }\end{array}$ & $\begin{array}{c}\text { Std. Error of } \\
\text { the Estimate }\end{array}$ & $\begin{array}{r}\text { Durbin- } \\
\text { Watson }\end{array}$ \\
\hline 1 & $0.606^{\mathrm{a}}$ & 0.368 & 0.333 & 0.42006 & 1.856 \\
\hline
\end{tabular}

b. Dependent Variable: FP

\section{B. Fit Test}

Model fit test uses the F Statistical Test to examine the effect of business age, financial management, investments opportunity and information technology on the financial performance of small and medium businesses. It was obtained the $F$ test result of 10,610 with a significance of 0,000 , that's means this research model was fit, it could be used to test the effect of the independent variable on the dependent variable.

TABLE 4. F TEST

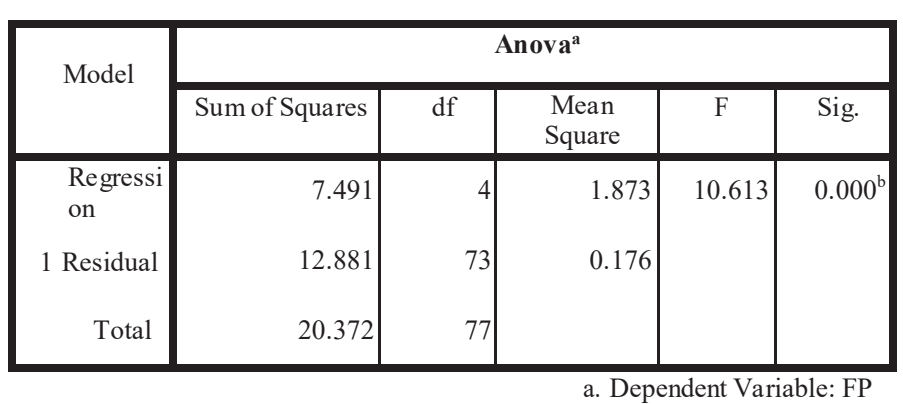

b. Predictors: (Constant), TI, BA, FM, PI

\section{Multiple Regression Testing}

The results of multiple regression tests to see the effect of business age, financial management, investments opportunity and information technology on the financial performance of small and medium-sized businesses can be seen in the table 5. The results of multiple regression tests show that BA (Business Age) and PI (Investment opportunity) significantly influence the company's financial performance. While the IT (Information Technology) and FM (Financial Management) variables do not significantly influence the company's financial performance.

These results indicate that the longer a company is established it usually has better financial performance. This is because they have a better understanding of the market and they have a brand that is already well known by the market. The results also show that companies that are willing to invest in $R \& D$ and production machinery will have better financial performance. The results of the production of batikcloth will be easily absorbed by the market. This is because the production of batik cloth is a type of creative business that is largely determined by the colors, patterns, production techniques.

FM (Financial Management) variable does not significantly influence the company's finansial performance, because from the sample data used in this study, most of the batik small entrepreneurs in Lasem have not done financial management and do not have good accounting records. They only record the incoming and outgoing money. Most of them do not even know how to calculate the cost of goods manufactured, gross profit and net profit.

IT variables do not affect the company's financial performance. This is because almost all respondents have not used information technology as a tool in managing their business activities. They still use the manual system in running their business. 
TABLE 5. MULTIPLE REGRESSION TESTING

\begin{tabular}{|c|c|c|c|c|c|c|c|}
\hline \multirow[t]{2}{*}{ Model } & \multicolumn{2}{|c|}{$\begin{array}{l}\text { Unstandardized } \\
\text { Coefficients }\end{array}$} & \multirow{2}{*}{$\begin{array}{c}\begin{array}{c}\text { Standar } \\
\text { dized } \\
\text { Coeffici } \\
\text { ents }\end{array} \\
\text { Beta }\end{array}$} & \multirow[t]{2}{*}{$t$} & \multirow[t]{2}{*}{ Sig. } & \multicolumn{2}{|c|}{$\begin{array}{l}\text { Collinearity } \\
\text { Statistics }\end{array}$} \\
\hline & B & $\begin{array}{l}\text { Std. } \\
\text { Error }\end{array}$ & & & & $\begin{array}{c}\text { Tolera } \\
\text { nce }\end{array}$ & VIF \\
\hline $\begin{array}{l}\text { Consta } \\
\text { nt }\end{array}$ & 0.726 & 0.169 & & 4.297 & 0.000 & & \\
\hline BA & 0.274 & 0.045 & 0.581 & 6.140 & 0.000 & 0.967 & 1.034 \\
\hline FM & -0.086 & 0.076 & -0.118 & -1.130 & 0.262 & 0.793 & 1.261 \\
\hline PI & 0.227 & 0.081 & 0.310 & 2.805 & 0.006 & 0.710 & 1.409 \\
\hline TI & -0.119 & 0.079 & -0.163 & -1.505 & 0.137 & 0.738 & 1.354 \\
\hline
\end{tabular}

\section{CONCLUSION AND IMPLICATIONS}

\section{A. Conclusion}

The conclusions that can be drawn from this study are : (1) for small and medium-sized enterprises (SMEs), the company's age and willingness to make investments opportunity greatly affect the company's financial performance. (2) IT support and good financial management in small and medium enterprises (SMEs) do not affect the company's financial performance. This is because most of them have not yet implemented IT support and good financial management. Different research results might be obtained if some of the respondents already use IT support and apply good financial management.

\section{B. Implication}

The next research can take a more varied sample of companies in terms of utilizing IT support and financial management capabilities. The results of this research can also be the basis for the government or decision makers to start encouraging SMEs to use information technology support in conducting their business, as well as fostering small and medium entrepreneurs in managing their company's finances to become more professional.

\section{REFERENCES}

[1] R. Alasadi and A. Abedelrahim," Critical Analysis and Modeling of Small Business Performance (Case Study: Syria)", Journal of Asia Entrepreneurship and sustainability, 3 (2), pp. 320-355, 2007.

[2] G.Chandler and S.Hanks, "Measuring The Performance of Emerging Business", Journal of Business Venturing, 8, pp.391-408, 1993.

[3] G.Chandler and S.Hanks, "Market Attractiveness, Resource-Based Capabilities, Venture Strategies, and Venture Performance”, Journal of Business Venturing, 9, pp.331-349, 1994.

[4] B. Chiappetta, K. Shaw and J. Wild, Principle of Financial Accounting, 19th ed, New York: McGraw-Hill Irwin, 2009.
[5] N.C. Churchill and V.L.Lewis, The Five Stages of Small Business Growth. Harvard Business Review, 61(3), pp.30-50. 1983.

[6] M.Cowling, Early Stage Survival and Growth, In: Parker S. (ed), Handbook of Entrepreneurship Research: The Life Cycle of Entrepreneurial Ventures, Heidelberg: Springer, pp. 477-504, 2006.

[7] R. Durand and R. Coeurderoy, "Age, Order of Entry, Strategic Orientation and Organizational Performance", Journal of Business Venturing, 16, pp. 471-494,2001

[8] M. A. A. Fouad, "Factors Affecting The Performance of Small and Medium Enterprises (SMES) In The Manufacturing Sector of Cairo, Egypt". International Journal Of Business And Management Studies, Vol 5, No 2, 2013, ISSN: 1309-8047, pp.157-166, 2013

[9] S. Haag and P. Keen, Information Technology: Tomorrow's Advantage Today. Hammond: Mcgraw-Hill College, 1996.

[10] A. Heshmati and H. Loof, "Investment and Performance of Firms: Correlation Or Causalty?" Corporate Ownership \& Controls , Volume 6, Issue 2, Winter 2008, pp.268 - 282, 2008

[11] Indonesian Government. (2008). Law No 20 of 2008 Concerning Micro, Small and Medium Enterprises (MSME). Indonesia, 2008

[12] L.N. Istanti, "Effects of Stock Prices, Trading Volume Activity and Stock Risk on Bid Ask Spread (Study on LQ-45 Companies on the Jakarta Stock Exchange)" Journal of Modernization Economics, Vol. 5 No. 3, pp. 199-210, 2009

[13] C. I. Jones, “ R\&D Based Economic Models of Economic Growth”, The Journal of Political Economy 13(4), pp.759-784, 1995

[14] Kasmir and Jakfar, Business Feasibility Study. Rev.Edition. Kencana Prenada Media.Jakarta, 2012

[15] Ministry of Cooperatives and Small and Medium Enterprises, Profile of Micro, Small and Medium Enterprises. Indonesia, 2012

[16] G.B. Murphy, J.W. Trailer and R.Hill, "Measuring Performance in Entrepreneurship Research”, Journal of Business Research, vol.36(1), pp. 15-23, 1996.

[17] D.M. Nthenge and J. Ringera, "Effect Of Financial Management Practices on Financial Performance of Small and Medium Enterprises in Kiambu Town, Kenya", American Based Research Journal, Vol-6Issue-1 Jan-2017 ISSN (2304-7151), pp.6-32, 2017.

[18] P. Nunes, M. Gonçalves, Z. Serrasqueiro," The Influence of Age on SMEs' Growth Determinants: Empirical Evidence", Small Business Economics, 40(2), pp.249-272 2013.

[19] A. Olusola and Y. Oluwaseun, "An Appraisal of the Impact of Information Technology (IT) on Nigeria Small and Medium Enterprises (SMEs) Performance", International Journal of Academic Research in Management (IJARM), Vol. 2, No. 4, pp. 140-152, 2013

[20] V.J.Reenen, 'Why has Britain had slower R\&D growth?'. Research Policy 26, pp. 493-507, 1997

[21] S.I.Y. Takahashi, "Entrepreneurs as Decisive Human Resources and Business. Performance for The Lao SMEs", Chinese Business Review, 8 (7), pp. 29-47, 2009

[22] J.Y.L.Thong, "An integrated Model of Information Systems Adoption in Small Business" Journal of Management Information Systems, 15(4), pp.187-214, 1999.

[23] Z. Tuanmat and M. Smith, "The Effect of Changes in Competition, Technology and Strategy on Organizational Performance in Small and Medium Manufacturing Companies", Asian Review of Accounting, 19(3), pp. 208-220, 2011

[24] B. Urban, " Understanding The Moderating Effect of Culture and SelfEfficacy on Entrepreneurial Intentions". Doctoral thesis submitted at the University of Pretoria in April 2004.

[25] S. Vassilakis, “ Learning-by-doing. In: Durlauf, SN, Blume, LE (Eds.) The New Palgrave Dictionary of Economics", 2nd ed. Palgrave Macmillan, 2008

[26] B.K. Williams and S.C. Sawyer, Using Information Technology: A Practical Introduction to Computers and Communications, 7th Ed. Boston, [Mass.]. London : McGraw-Hill/Irwin, 2003.

[27] T. Yasuda, "Firm Growth, Size, Age and Behavior in Japanese Manufacturing”. Small Business Economics, 24(1), pp. 1-15, 2005. 